\title{
Penentuan Zona Dan Karakteristik Daerah Aliran Sungai Dengan Analisa Spasial Sistem Informasi Geografis
}

\section{Determination of Zone and Characteristics Watershed with Spatial Analysis of Geographical Information System}

\author{
Era Alfansyuri ${ }^{1)} \&$ Indra Farni $^{2)}$ \\ ${ }^{1)}$ Jurusan Teknik Sipil Politeknik Negeri Padang Kampus Limau Manis Padang \\ Telp. 0751-72590 Fax. 0751-72576 Email: eraalfansyuri@yahoo.com \\ ${ }^{2)}$ Jurusan Teknik Sipil Universitas Bung Hatta Padang
}

\begin{abstract}
Watershed Management comprehensively considers the boundaries and characteristics of physical watersheds that have precision and detail of data sources. Determination of the Watershed zone in a digital process is supported by the development of satellite-based remote sensing surface data and supported by spatial data analysis management technology with Geographic Information System. Provincial spatial boundaries and watershed characteristics include the area, slope and land use in the area so as to support the watershed management.
\end{abstract}

Keywords: Watershed, Spatial Analyst, Geographic Information System

\section{PENDAHULUAN}

Salah satu komponen penting dalam pengelolaan DAS adalah menentukan secara fisik batas DAS beserta karakteristik dari masing-masing DAS atau subDAS penyusun dari DAS itu sendiri, yang meliputi luas, kemiringan dan arah aliran. Luasan DAS dibentuk oleh adanya perbedaan ketinggian permukaan (topografi) dan arah aliran permukaan. Untuk menentukan batasan DAS diperlukan data masukan berupa ketinggian titik-titik permukaan yang diperoleh baik dari data primer berupa pengukuran langsung dilapangan secara terestris dan perekaman dan pengolahan data secara penginderaan jauh (remote sensing) dalam bentuk data garis (vector) maupun data raster (image).

Sesuai dengan perkembangan teknologi pengelolaan data maka penentuan bentuk permukaan DAS dapat dilakukan secara digital dengan memanfaatkan kemampuan analisa spasial dengan Sistem Informasi Geografis. SIG memiliki perangkat analisa spasial seperti pembuatan garis kontur, ( create contour) penentuan DAS (watershed
\& stream), serta penentuan kemiringan (slope)

Tujuan dari penelitian ini adalah untuk mendapatkan batas Daerah Aliran Sungai (DAS) beserta karakteristik secara fisik berupa kemiringan dan penggunaan lahan DAS dengan memanfaatkan kemampuan analisa spasial Sistem informasi Geografis

DAS menurut Dictionary of Scienctific and Technical Term (Lapedes et al., 1974), DAS (watershed) diartikan sebagai suatu kawasan yang mengalirkan air kesatu sungai utama. Dikemukakan oleh Manan (1978) bahwa DAS adalah suatu wilayah penerima air hujan yang dibatasi oleh punggung bukit atau gunung, dimana semua curah hujan yang jatuh diatasnya akan mengalir disungai utama dan akhirnya bermuara ke laut.

DAS dalam bahasa Inggris disebut Watershed atau dalam skala luasan kecil disebut dengan Catchment Area adalah suatu wilayah daratan yang dibatasi oleh punggung bukit atau batas-batas pemisah topografi, yang berfungsi menerima, menyimpan dan mengalirkan curah hujan yang jatuh di atasnya ke alur-alur sungai dan terus mengalir ke anak sungai dan 
kesungai utama, akhirnya bermuara ke danau/waduk atau ke laut.

Beberapa istilah yang perlu dipahami dan disepakati bersama dalam pengelolaan DAS adalah sebagai berikut:

a) Daerah Aliran Sungai (DAS) adalah suatu wilayah daratan yang merupakan kesatuan dengan sungai dan anak-anak sungainya yang dibatasi oleh pemisah topografis yang berfungsi menampung air yang berasal dari curah hujan, menyimpan dan mengalirkannya melalui ke danau atau ke laut secara alami.

b) Sub DAS adalah bagian DAS yang menerima air hujan dan mengalirkannya melalui anak sungai ke sungai utama. Setiap DAS terbagi habis ke dalam Sub DAS - Sub DAS.

c) Satuan Wilayah Sungai (SWS) adalah kesatuan wilayah pengelolaan sumberdaya air dalam satu atau lebih DAS dan atau satu atau lebih pulaupulau kecil , termasuk cekungan air bawah tanah yang berada dibawahnya.

d) Pengelolaan DAS adalah upaya manusia di dalam mengendalikan hubungan timbal balik antara sumberdaya alam dengan manusia di dalam DAS dan segala aktifitasnya, dengan tujuan membina kelestarian dan keserasian ekosistem serta meningkatkan manfaat sumberdaya alam bagi manusia secara berkelanjutan .

e) Pengelolaan DAS Secara Terpadu adalah suatu proses formulasi dan implementasi kebijakan dan kegiatan yang menyangkut pengelolaan sumberdaya alam, sumberdaya buatan dan manusia dalam suatu DAS secara utuh dengan mempertimbangkan aspekaspek fisik, sosial, ekonomi dan kelembagaan di dalam dan sekitar DAS untuk mencapai tujuan yang diinginkan.

f) Rencana Pengelolaan DAS merupakan konsep pembangunan yang mengakomodasikan berbagai peraturan perundang-undangan yang berlaku dan dijabarkan secara menyeluruh dan terpadu dalam suatu rencana berjangka pendek, menengah maupun panjang yang memuat perumusan masalah spesifik di dalam DAS, sasaran dan tujuan pengelolaan, arahan kegiatan dalam pemanfaatan, peningkatan dan pelestarian sumberdaya alam air, tanah dan vegetasi, pengembangan sumberdaya manusia, arahan model pengelolaan DAS, serta sistem monitoring dan evaluasi kegiatan pengelolaan DAS.

Perencanaan pengelolaan DAS terpadu mempersyaratkan adanya beberapa langkah-langkah penting meliputi pengumpulan data yang ekstensif, didukung oleh strategi pengelolaan data yang terpadu. Pengumpulan data ini terutama identifikasi karakteristik DAS yang, antara lain, mencakup batas dan luas wilayah DAS, topografi, geologi, tanah, iklim, hidrologi, vegetasi, penggunaan lahan, sumberdaya air, kerapatan drainase, dan karakteristik sosial, ekonomi dan budaya.

Sesuai dengan peraturan pemerintah no 37 tahun 2012 tentang DAS, perencanaan DAS dilakukan dengan melakukan inventarisasi DAS meliputi penetapan dan kualifikasi DAS. Proses dan penetapan batas DAS dilakukan melalui tahapan kegiatan penyiapan bahan, penentuan bataas DAS, verifikasi batas DAS dan penetapan batas.

Penentuan klasifikasi DAS dilakukan berdasarkan beberapa kriteria diantaranya kondisi lahan itu sendiri dan pemanfaatan ruang wilayahnya.

SIG merupakan teknik berbasis computer untuk memasukkan, mengolah, dan menganalisis data objek permukaan bumi dalam bentuk grafis, koordinat, dan data base, dimana hasilnya bisa menggambarkan sebuah fenomena spasial. Sesuai dengan fungsinya SIG dapat menggambarkan bentuk DAS sesuai dengan data yang di input (Mawardah, 2013)

Dalam penelitian ini menggunakan citra SRTM sebagai sumber data, dimana bisa 
diperoleh gambaran bentuk dan ketinggian permukaan bumi dalam bentuk data digital dengan tingkat resolusi tinggi

Perolehan data SRTM ini didapatkan dengan menngunakan instrument radar dimana untuk memperoleh topografi (elevasi) data, payload SRTM dilengkapi dengan dua aperture sintetis radar antena. Satu antena terletak di Shuttle payload, yang lain di ujung tiang dengan jarak 60 meter dari Shuttle payload pertama. SRTM memanfaatkan teknik yang disebut interferometri radar untuk memperoleh informasi topografi. Dalam radar interferometri, dua gambar radar yang diambil dari lokasi yang sedikit berbeda. Perbedaan antara gambar ini memungkinkan untuk perhitungan elevasi permukaan, atau perubahan. Pada SRTM, dua gambar radar yang diperlukan untuk melakukan interferometri yang diperoleh secara bersamaan oleh dua antena.

Ada dua jenis panel antena: C-Band dan $\mathrm{X}$-Band. Data radar C-band diproses di Jet Propulsion Laboratory (JPL) menyediakan Digital Elevation Model (DEM) global. DEM resolusi lebih tinggi yang dihasilkan dari data radar X-Band, diolah dan didistribusikan oleh German Aerospace Center, DLR.

\section{Sistem Informasi Geografis (SIG)}

Pada dasarnya, istilah Sistem Informasi Geografis (SIG) merupakan gabungan dari tiga unsur pokok yaitu : sistem, informasi, dan geografis. Istilah sistem dapat didefinisikan sebagai sekumpulan objek, ide berikut saling keterhubungannya (interrelasi) dalam mencapai tujuan atau sasaran bersama. Dan istilah geografis merupakan bagian dari spasial (keruangan) atau mengandung pengertian suatu persoalan mengenai bumi : permukaan dua atau tiga dimensi. Sedangkan informasi geografis mengandung pengertian informasi mengenai tempat-tempat yang terletak di permukaan bumi, pengetahuan mengenai posisi dimana suatu objek terletak di permukaan bumi, dan informasi mengenai keterangan-keterangan (atribut) yang terdapat di permukaan bumi yang posisinya diberikan atau diketahui. Jadi Sistem Informasi Geografis (SIG) merupakan suatu kesatuan formal yang terdiri dari berbagai sumber daya fisik dan logika yang berkenaan dengan objek-objek yang terdapat di permukaan bumi.

Teknik pemrosesan data image, data vektor, poligon, dan titik akan menggunakan layanan teknik analisa spasial dari perangkat lunak sistem informasi geografis.

Kemampuan SIG juga dikenali dari fungsifungsi analisis yang dapat dilakukannya. Secara umum, terdapat dua jenis fungsi analisis yaitu fungsi analisis spasial dan fungsi analisis atribut (basisdata atribut).

Fungsi analisis spasial ini terdiri dari :

1. Klasifikasi (reclassify), fungsi ini mengklasifikasikan atau mengklasifikasikan kembali suatu data spasial atau data atribut menjadi data spasial yang baru dengan menggunakan kriteria tertentu.

2. Overlay, fungsi ini mengasilkan data spasial baru minimal dari dua data spasial yang menjadi masukkannya. fungsi analisis spasial overlay akan dikenakan terhadap ketiga data atribut tersebut.

3. Buffering, fungsi ini akan menghasilkan data spasial baru yang berbentuk poligon atau zone dengan jarak tertentu dari data spasial yang menjadi masukannya. Data spasial tidak akan menghasilkan data spasial baru yang berupa lingkaranlingkaran yang mengelilingi titik-titik pusatnya. Untuk data spasial garis akan menghasilkan data spasial baru yang berupa poligon-poligon yang melingkupi garis-garis. Demikian pula untuk data spasial poligon, akan menghasilkan data spasial baru yang berupa poligonpoligon yang lebih besar dan kosentris.

4. Digital Image Processing (pengolahan citra dijital), fungsi ini dimiliki oleh perangkat SIG yang berbasis raster. Karena data spasial permukaan bumi (citra dijital) banyak didapat dari perekaman data satelit yang berformat 
raster, maka banyak SIG raster yang juga dilengkapi dengan fungsi analisis ini.

\section{METODOLOGI}

Penentuan DAS dan karakteristik DAS berlokasi pada kawasan perkotaan Batusangkar Kabupaten Tanah Datar yang dibatasi oleh koordinat $0^{\circ} 30$ ' 54.75" S, $100^{\circ} 30^{\prime} 25.33^{\prime \prime} \mathrm{E}$ dan $0^{\circ} 22^{\prime} 31.82$ ' S, $100^{\circ}$ 38 ' 50.97" E yang mempunyai kondisi topografi bervariasi mulai dari datar, bergelombang hingga berbukit dengan elevasi berkisan antara $450-800 \mathrm{~m}$ di atas permukaan laut serta mempunyai kemiringan yang beragam. Dengan kondisi topografi yang beragam ini akan menghasilkan subdas-subdas dalam jumlah yang besar.

Penentuan watershed dan stream secara interpretasi manual sangat tergantung kepada penafsiran secara subjectif selain itu juga akan membutuhkan ketelitian dan waktu yang cukup lama.

Untuk penentuan kawasan DAS beserta karaktersitiknya secara analisa spasial GIS maka dilakukan beberapa tahap pekerjaan meliputi :

- penyiapan data masukan berupa data image citra serta pengaturan sistem koordinat citra.

- Melakukan analisis image berupa pembuatan watershed dan stream

- Pengelolaan data GIS dan geoprocessing serta analisis spasial GIS untuk mendapatkan karakteristik fisik watershed

- Membuat rancangan layout dan tabel

Penyiapan data

Untuk mendapatkan bentuk permukaan DAS diperoleh dengan memanfaatkan citra (image) yang diperoleh dari citra SRTM dengan mengatur sistem proyeksi dan sistem koordinat yang digunakan.

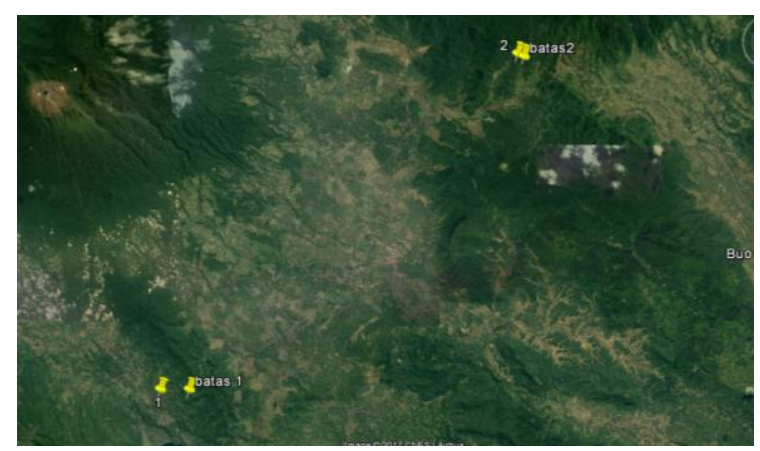

Gambar 1. Tampilan citra kawasan

Proyeksi sistem koordinat :

- WGS_1984_UTM_Zone_47S

- Projection: Transverse_Mercator

- False_Easting: 500000.00

- False_Northing: 10000000.00

- Central_Meridian: 99.00

- Scale_Factor: 0.999600

- Latitude_Of_Origin: 0.00

- Linear Unit: Meter (1.000000)

Sistem Koordinat Geografik :

- GCS_WGS_1984

- Angular Unit: Degree (0.017453292519943299)

- Prime Meridian: Greenwich (0.0000)

- Datum: D_WGS_1984

- Spheroid: WGS_1984

- Semimajor Axis: 6378137.000

- Semiminor Axis: 6356752.31424517930

- Inverse Flattening: 298.25722356300003

Sehingga diperoleh tampilan citra SRTM seperti berikut

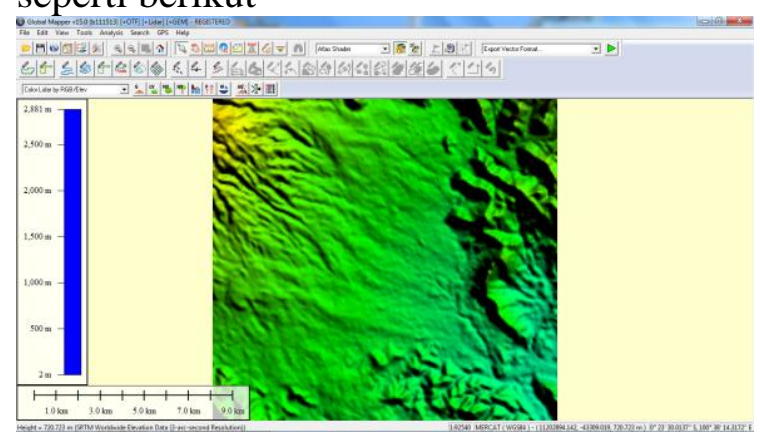

Gambar 2. Model 3D kawasan 
Dari peta SRTM selanjutnya dilakukan analisis berupa pembuatan garis kontur dari grid terrain dengan interval kontur yang disesuaikan dengan kebutuhan.
Tahapan tersebut dapat dilihat pada diagram berikut :

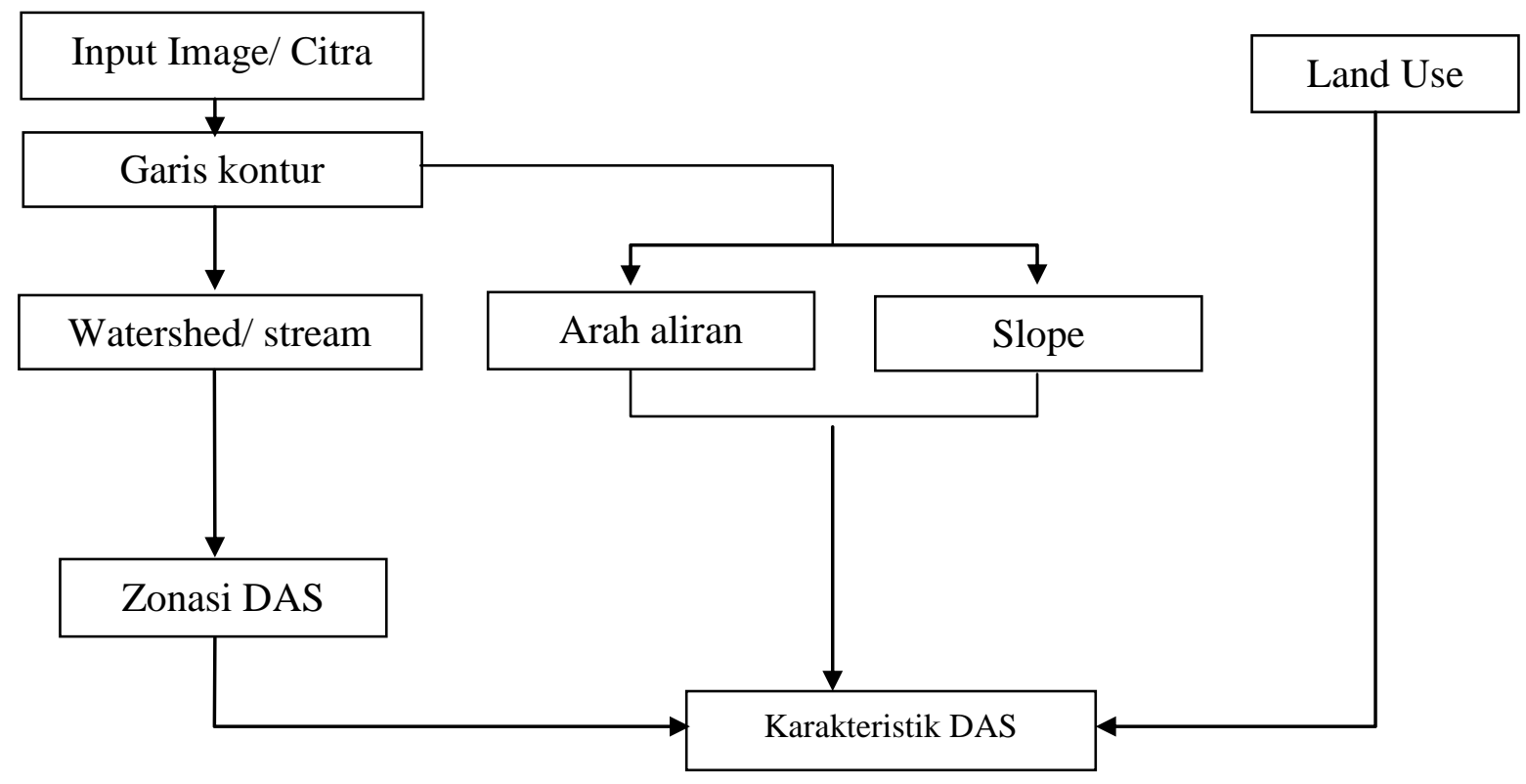

Gambar 3. Diagram Alir

\section{HASIL DAN PEMBAHASAN}

Penentuan watershed dan stream dilakakukan dengan menggunakan perangkat lunak Globat Mapper dimana algoritma yang umum digunakan adalah menggunakan metode D8 methode (Tarboton, 1989 ; Traboton and Bras, 1991) dimana hasil analisis dengan membandingkan ketinggian relatif satu piksel terhadap 8 (delapan) piksel disekelilingnya. Selanjutnya arah aliran ditentukan dari kemiringan tercuram terhadap piksel sekelilingnya

\section{Pembuatan peta kontur}

Pembuatan peta kontur dengan menggunakan data citra SRTM dengan mengatur interval ketinggian.

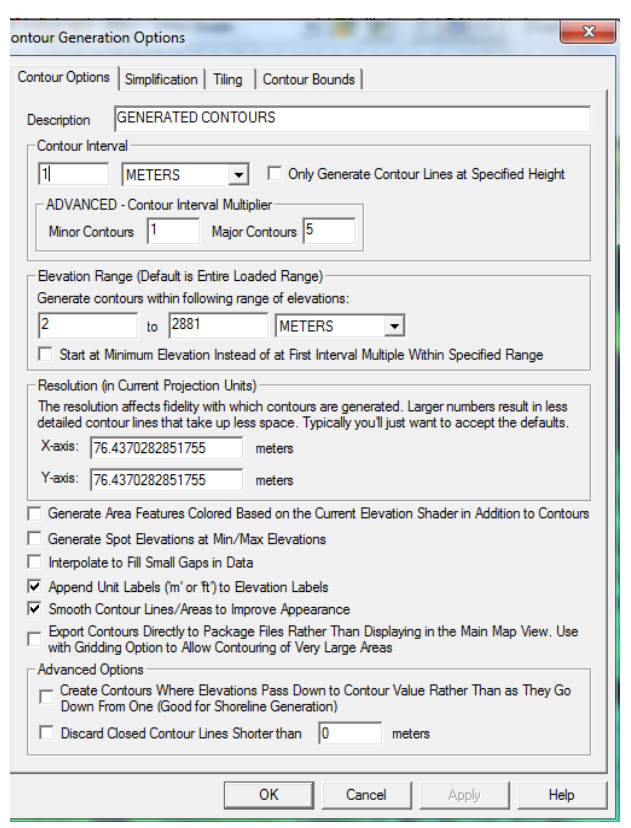

Gambar 4. Pengaturan pembuatan kontur 
Sehingga diperoleh gambaran garis ketinggian (kontur) permukaan kawasan sebagai berikut :

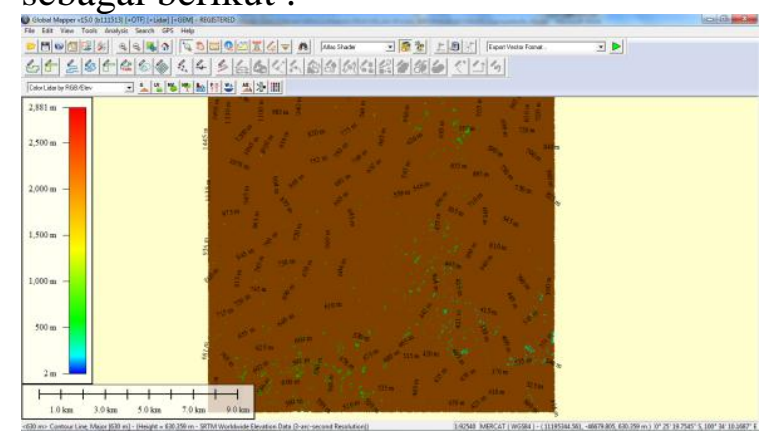

Gambar 5. Hasil pembuatan garis kontur

\section{Analisa watershed}

Dari analisa spasial GIS diperoleh 51 subwatershed yang tersebar di kawasan Hasil penentuan subwatershed dapat dilihat pada gambar berikut :

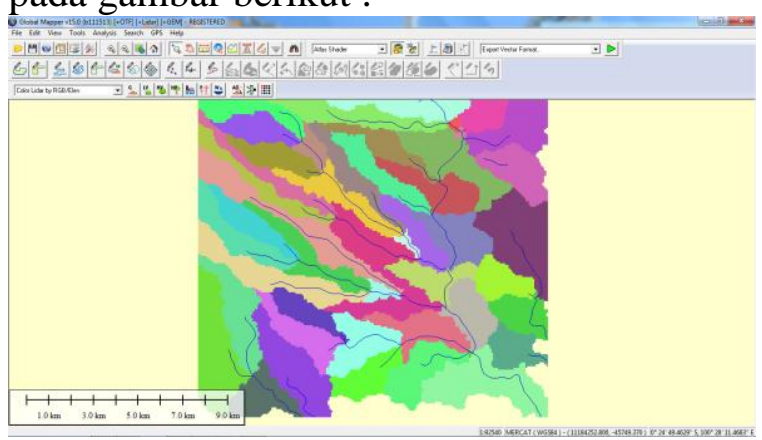

Gambar 6. hasil pembagian sub watershed

\section{Zonasi kawasan DAS}

Dengan mempertimbangkan arah aliran permukaan dan aliran sungai yang ada maka dilakukan pengelompokkan subwatershed menjadi zonasi kawasan DAS yang dikelompokkan menjadi 7 (tujuh) zona watershed

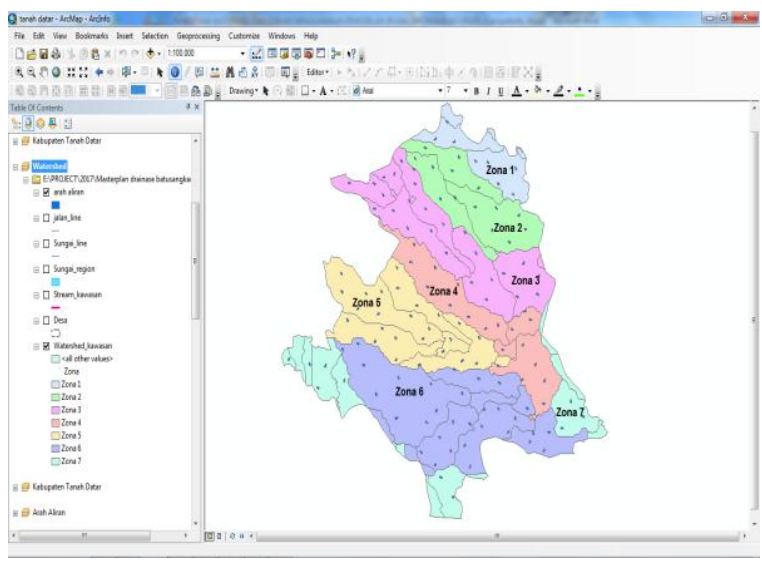

Gambar 7. Pembagian Zona DAS

Tabel 1. Luas Watershed

\begin{tabular}{|c|c|r|}
\hline Zona & Sub watershed & \multicolumn{1}{l|}{ Luas (Ha) } \\
\hline 1 & 6 & 682.076 \\
\hline 2 & 3 & 1358.499 \\
\hline 3 & 7 & 2051.699 \\
\hline 4 & 5 & 1972.296 \\
\hline 5 & 6 & 1972.296 \\
\hline 6 & 10 & 2937.966 \\
\hline 7 & 14 & 1275.356 \\
\hline Jumlah & 51 & 12250.188 \\
\hline
\end{tabular}

\section{Analisa kemiringan kawasan}

Peta kemiringan kawasan diperoleh dari analisa spasial dari data kontur menjadi data DEM (Digital Elevation Model) dengan melakukan pengaturan terhadap nilai piksel. Dengan analisa 3D analiyst dimana data permukaan dalam bentuk raster diolah menjadi data kemiringan (slope) yang diklasifikasikan dengan satuan persen.

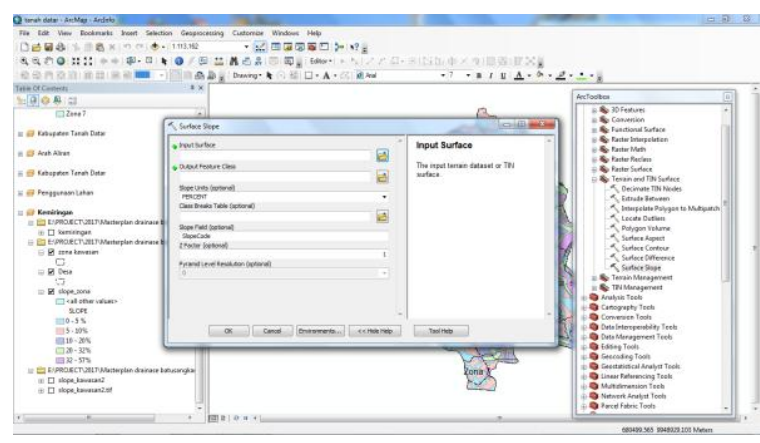

Gambar 8. Pengaturan pembuatan kemiringan

(slope)

Untuk membuat klasifikasi lereng maka perlu dilakukan pengaturan kelas (reclassify) secara natural breaks menjadi 5 slope, 0 - $5 \%, 5$ - 10\%, 10 - 20\%, 20 $32 \%$ dan $32-57 \%$ 


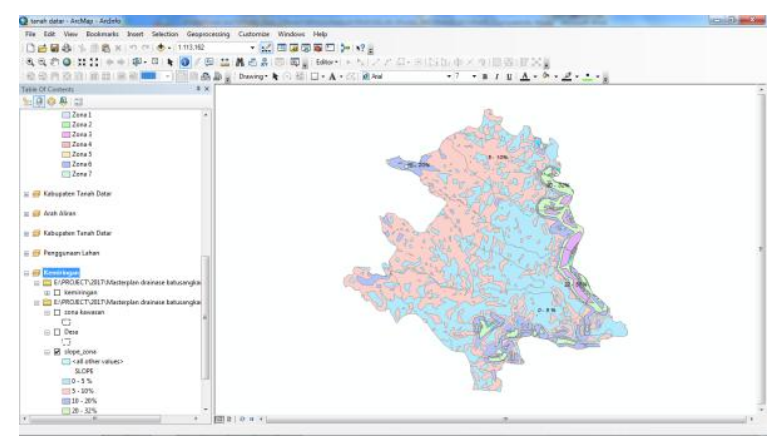

Gambar 9. peta kemiringan kawasan

Tabel 2. Luas kemiringan DAS setiap Zona

\begin{tabular}{|c|c|c|c|c|c|}
\hline \multirow[b]{2}{*}{ Zona } & \multicolumn{5}{|c|}{ Luas (Ha) } \\
\hline & $0-5 \%$ & $5-10 \%$ & $10-20 \%$ & $20-32 \%$ & $32-57 \%$ \\
\hline Zona 1 & 31988 & 28268 & 4293 & 3170 & 48 \\
\hline Zona 2 & 335.08 & 802.42 & 52.15 & 145.22 & 23.64 \\
\hline Zona 3 & 741.03 & 858.96 & 251.37 & 110.93 & 89.41 \\
\hline Zona 4 & 636.69 & 535.70 & 55.40 & 78.03 & 94.97 \\
\hline Zona 5 & 771.08 & 1162.43 & 38.79 & 0 & 0 \\
\hline Zona 6 & 1323.75 & 1052.83 & 451.39 & 110.00 & 0 \\
\hline Zona 7 & 446.59 & 519.02 & 206.65 & 95.89 & 6.09 \\
\hline Jumlah & 4574.08 & 5214.03 & 1098.68 & 571.76 & 219.01 \\
\hline
\end{tabular}

Secara grafik penyebaran kemiringan disetiap zona dapat dilihat pada gambar berikut :

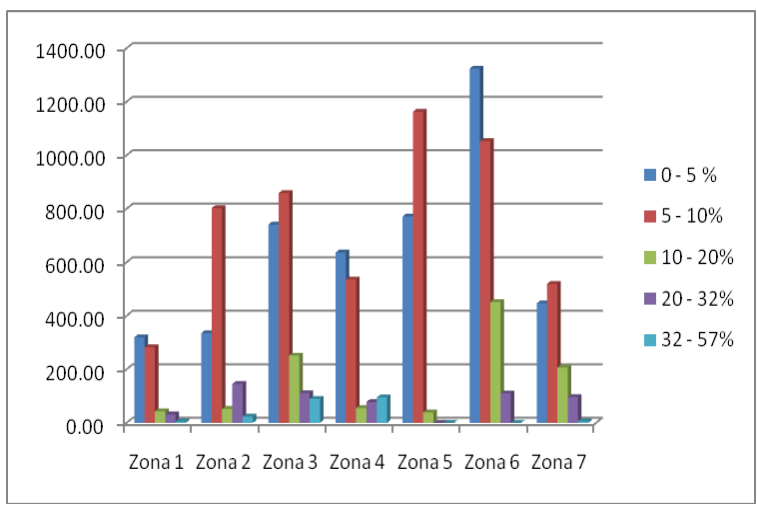

Gambar 10. grafik kemiringan zona

Untuk kebutuhan geoprocessing analyst maka dilakukan perubahan bentuk format dari data raster manjadi data vektor

\section{Analisa Penggunaan lahan kawasan}

Analisa Penggunaan lahan kawasan diperoleh dari tahapan overlay data penggunaan lahan RTRW Kabupaten dengan zona DAS yang meliputi hutan rakyat, pemukiman, lapangan diperkeras, sawah, semak belukar, tanah kosong, tegalan dan kebun

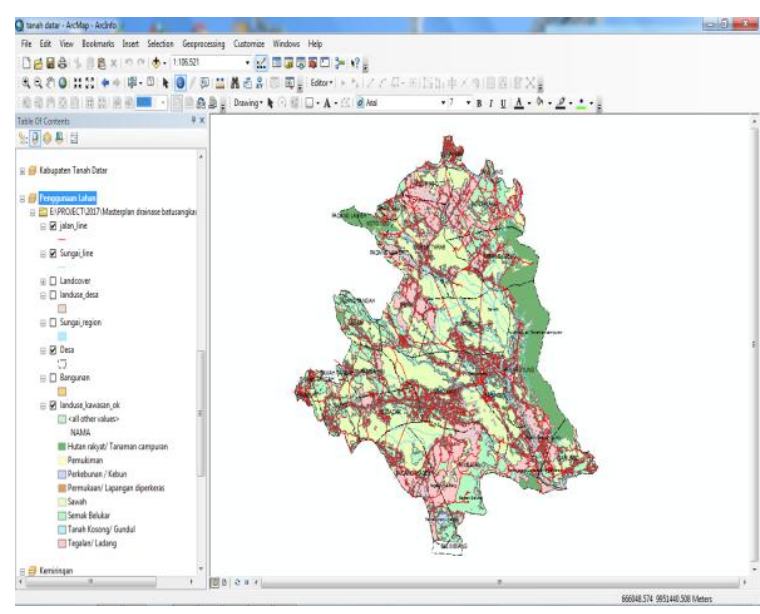

Gambar 11. Peta penggunaan lahan kawasan 


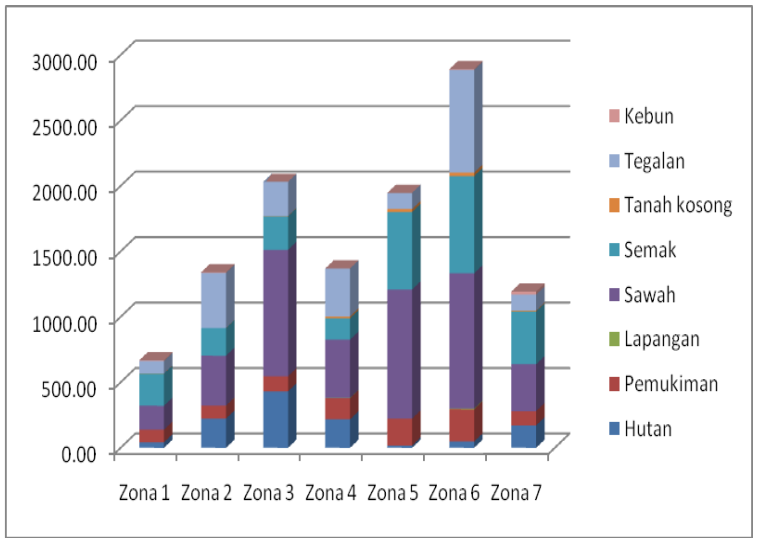

Gambar 12. Grafik penggunaan lahan zona

\section{Penyajian DAS}

Penyajian data dilakukan dalam bentuk format data spasial dalam sebuah peta dengan sistem koordinat dan skala tertentu dan menggunakan kaidah-kaidah kartografi. Selain itu juga dilengkapi dengan data atribut yang tersusun dalam sebuah basis data

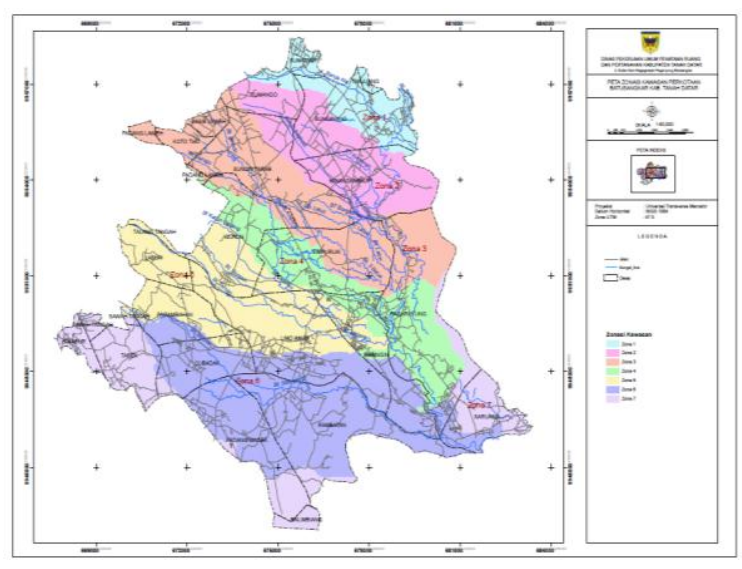

Gambar 13. Tampilan Zona DAS kawasan

Tabel 3. Data penggunaan lahan setiap zona Watershed

\begin{tabular}{|c|r|r|r|r|r|r|r|r|}
\hline $\begin{array}{c}\text { Zona } \\
\text { (Ha) }\end{array}$ & $\begin{array}{c}\text { Hutan } \\
\text { rakyat }\end{array}$ & Pemukiman & $\begin{array}{c}\text { Lapangan } \\
\text { diperkeras }\end{array}$ & \multicolumn{1}{c|}{ Sawah } & $\begin{array}{c}\text { Semak } \\
\text { Belukar }\end{array}$ & $\begin{array}{c}\text { Tanah } \\
\text { Kosong }\end{array}$ & Tegalan & Kebun \\
\hline Zona 1 & 42.73 & 95.29 & 0.00 & 183.12 & 245.90 & 1.74 & 93.90 & 5.27 \\
\hline Zona 2 & 223.40 & 98.81 & 0.84 & 380.24 & 210.41 & 1.55 & 420.24 & 5.42 \\
\hline Zona 3 & 431.04 & 115.12 & 0.00 & 965.88 & 255.94 & 2.35 & 260.85 & 0.00 \\
\hline Zona 4 & 217.40 & 160.75 & 2.79 & 445.10 & 163.92 & 13.18 & 366.47 & 0.00 \\
\hline Zona 5 & 17.31 & 206.00 & 0.00 & 985.41 & 592.19 & 22.17 & 123.65 & 0.00 \\
\hline Zona 6 & 48.06 & 245.91 & 6.16 & 1032.57 & 742.25 & 26.35 & 784.44 & 5.52 \\
\hline Zona 7 & 171.67 & 108.54 & 0.00 & 357.84 & 403.66 & 5.85 & 122.47 & 23.07 \\
\hline Jumlah & 1151.62 & 1030.43 & 9.79 & 4350.17 & 2614.28 & 73.18 & 2172.03 & 39.29 \\
\hline
\end{tabular}

\section{SIMPULAN}

Diperoleh tujuh zona daerah aliran sungai pada kawasan secara spasial dalam sistem informasi geografis dengan dilengkapi data atribut DAS meliputi kemiringan dan penggunaan lahan kawasan.

\section{DAFTAR PUSTAKA}

[1] Bagusrama. 2011. Definisi-definisi Daerah Aliran Sungai (DAS). Wordpress.com

[2] Mawardah Nur Hanifiyani, Dkk , Analisis Karakteristik DAS Menggunakan Perangkat Lunak Sistem Informasi Geografis, 2013, 
Laboratorium Hidrologi Hutan dan Pengelolaan DAS. IPB

[3] Pembuatan Arah Aliran dan Akumulasi Aliaran Air (Watershed) Dengan Arcgis 10, Juni 2014, Air Itu Mengalir. Yoghagen.Blogspot.Com
[4] Peraturan Pemerintah No 37 Tahun 2012 Tentang Pengelolaan Daerah Aliran Sungai SRTM-Shutle Radar Tophographic Mission, Terraimage.com 